\title{
Deconstruction of Accounting Earnings With Sharia Concept
}

\author{
Amir \\ Universitas Muhammadiyah Purwokerto \\ Student of Doctoral Program of Accounting at Airlangga University \\ amireset@yahoo.com
}

\begin{abstract}
This article aims to begin deconstructing the concept of sharia accounting profit. The concept of sharia accounting profit is currently adopted from the conventional capitalist accounting profits. Philosophically, there is a difference between the concept of conventional accounting profit and sharia accounting profit. Deconstruction of sharia accounting profit aims to find a broader meaning of sharia accounting profit in order to build concepts and accounting profit model with sharia perspective based on Al-Qur'an and Hadith of the Prophet SAW who Sahih.
\end{abstract}

Keywords: Deconstruction, Acconting Earnings, Sharia.

\section{INTRODUCTION}

The current conventional accounting practice is the result of capitalist society thinking which emphasizes the process of accumulation of wealth and control of resources in the hands of capitalists (capital owners) [1]. Ikatan Akuntan Indonesia (IAI) has been accomodated Syariah Accounting in Financial Accounting Standards Guidelines (PSAK) 101. Sharia Financial Statement that include sharia entity is an entity which performs sharia transaction as business activity based on sharia principles stated in its articles of association. Thus, a sharia entity is in its activities based on Sharia principles, ranging from its philosophy, business process, financial statements, to the distribution of the results of its economic activities (profit) to the parties concerned and entitled to get it, and based on the Holy Qur'an and Hadist Sahih, as well as business practices ever existed in Islamic history.

[2] Sharia accounting development is not only related to the fundamental aspects of epistimology such as the concept of Islamic transactions; mudaraba, musharaka, wakalah bil Ujrah, Qard, Murabaha, Salam / Istisha and Hawalah, which implies sharia-based accounting theory, but also related to the syariah purpose (maqashi syari'ah), syariah parameters to evaluate and formulate the rules of syariah financial instrumentation. The criticisms of sharia accounting practices that adopt conventional accounting are the use of cash basis and / or accrual basis, due to the uncertainty of the use of accrual basis method to recognize future income, lead to the element gharar (speculation)[3]. One of the concepts of sharia accounting that is still less attractive is about the "profits". The Profits have been interpreted to be limited to operating income as measured by net cash generated over a certain period [4]. In the theory of conventional accounting entities, profit is the difference between income and expenses. The problem is whether a post (account) is a cost or a profit sharing? [5] and must be linked to the entity concerne, to whom will the amount of rupiah earned be distributed? Thus, profits are distributed to parties such as investors, managers and employees, creditors, government and other entities.

The concept of profit in Shariah entities is based on Tauhid (Lillah). Since the basis of ownership in the entity of sharia is all that exists in this world belongs to God, the distribution of profit of an entity must be adapted to the guidance contained in the Qur'an and hadith saheeh Prophet SAW without abandoning existing practices in accordance with the rules syar'iyah.

Objectives of this article is to describe the profit of sharia accounting in accordance with Al-Qur'an and Hadith Sahih on the entity of sharia. The urgency on sharia accounting profit are;

a. The concept of conventional accounting profit is capitalist materiality which less in accordance with the teachings of Tauhid.

b. The profit in sharia entities adopts the concept of conventional accounting profit and modifies only by listing and subtracting net income by zakah by $2.5 \%$. This is not perfect because it could be the rights of other parties that should be removed from net profit has not been distributed properly.

\section{CONVENTIONAL ENTITIES AND SHARIA ENTITIES}

Entity theories are usually associated with the involvement of various parties in economic activity, such as managers, employees, creditors, investors, government and other entities. These parties are the beneficiaries of the activities and the added value of the company's economic activities [6]. The company is a stand-alone entity and separate from the owner of the fund or investor. Because the focus of accounting is on the company, the resulting financial statements are a form of management accountability for the management of funds to owners or investors.

The Islamic sharia underlying economic and financial activities emphasizes that all activities and activities of life including economics are humanity and humanity to God [7]. Thus, sharia accounting should also be compiled, reported and used as one of the decisions for divine interest. Islamic economics, the absolute 
possession of all that exists in this world is God's absolute right. While managers, investors, employees and other parties related to economic business, the same as the manager or representative of God. Therefore, the management should be responsible to God and not just to the other parties concerned, such as investors, creditors, employees and the government and others.

\section{SHARIA ACCOUNTING WORTHY OF WORSHIP}

Profits are conventionally defined only as the difference between income and expenses incurred in a business entity. Owing to this, profit utilization is usually only shared in the form of retained earnings for the benefit of corporate development and dividends to the owner of the company based on the number of shares [8], a basis for taxation, determinants of dividend payout policies, investment guidelines, and decision making, and elements of prediction (Belkaoui: 1993), and indicator for assessing and measuring management achievement [9].

It is stated that PSAK No.1 in par. 81, "the entity in disclosing the items in the statements of comprehensive income as an income statement for the period of profit and loss attributable to non-controlling interests and "entity owner". Whereas, in PSAK 101 par. 20, the presentation of financial statements should provide information relevant to the needs of users of the report for decision-making and reliability, with the understanding: (i) reflects the honesty of the presentation of results and financial position "entity sharia ". The next debatable issue than are "Who is the "owner of the absolute entity" and "Who is entitled to take precedence in the earnings gain?"

\section{RECORDING BUSINESS TRANSACTIONS IS COMMAND FROM GOD}

Islam as a universal religion that God direct revealed through Prophet SAW explicitly requires to record every business transaction. For most people, accounting records are merely records and there is no value of worship. But Allah immediately gave orders to the believers to record the transaction of accounts payable and business transactions. Albaqarah 282: "who believe! If you do not do in cash for a prescribed time, you should write it down....."

There are some points that need to be focused on:

1. Business record (accounting) is a direct division of God. Therefore, in recording there are values of worship and in turn will get reward from God.

2. Recording business transactions is to increase the devotion to God. However, the discussion in more likely on how the form of devotion can be implemented and recorded in the accounting records?

\section{BASIC PHILOSOPHICAL PROFIT OF SHARIA ACCOUNTING}

The basic guideline for the development of shari'a accounting sciences is Al-Qur'an \& Hadith Sahih. Thus, the discussion of spiritual accounting profit should also be returned to the Qur'an and Hadith Sahih and interpret the intentions contained in the verses of the Qur'an and Hadith to enrich and strengthen the concept of shari'ah accounting.

The discussions of spiritual accounting profit that we need to understand is; first of all that this universe is essentially belonging to God.

"It belongs to the kingdom of the heavens and the earth, He lives on and off, and He is Almighty over all things." (QS. Al-Hadid; 2)

From this verse, it can be explained that the universe belongs to Allah SWT, hence in the establishment of a business entity should also be aware that the ultimate owner and absolute owner of the company is Allah SWT. Thereby, the shareholder is a representative (khalifah) of God who is expected to manage the earth and the company is mandated and does not do damage in managing the company. As stated in Surah Al-Baqarah 30:

"Remember when your Lord said to the Angels:" I will make a caliph in the earth ".

This verse explains the position of man as the representation of God as the owner of heaven and earth. Therefore, the true owner of the profits earned by the company is God's absolute right. As a result, the utilization of corporate profits must also be in accordance with the provisions of Allah SWT. Second, Shariah accounting profit is profit that must be utilized for the sake of worship. Allah in alqur'an surah adz-dzariat: 56,

"And I did not create jinn and men but that they might serve me"

Man was created by God to worship only to Him. During this worship is only understood as a ritual such as praying, fasting, giving zakat, having pilgrimage and other ritual worship. Worship should be understood as all activities during life in the world in order to establish a company (corporate) then it should be intended also to worship. Therefore, any accounts contained in the financial statements should also be worthy of worship, including profits.

\section{Deconstruction of Sharia Accounting Profit}

According to Derrida, deconstructing something does not mean omitting it completely, but seeing something that has been dominating from different sides. Another meaning is expected to provide a meaning that may be better than before (Riduwan et al, 2010). Therefore, this article will intend to conceptual deconstruction of profit from the spiritual dimension of sharia. As mentioned above, in Shariah entity is always comes first and the main reference is Al-Quran. One of the meanings of profit is in the letter of Al-Mukminun 1-11 is:

"Certainly will the believers (Company) have succeeded (profit), Khusu' in Shalat, Who avoid vain talk: zakat........"

The word "qod aflaha" above in Indonesia means that it has indeed been fortunate (profit) if a certainty will get what coveted by the believers. If this verse is interpreted into the field of economy or a business then the word "mukminun" which means plural (many), can be translated in a collection of believers who founded a company. So far, the plural word like mukminun has 
never been translated in a business entity or company. If the word mukminun can be translated as a collection of people within a company and they believe, then the development of shari'ah accounting will be wider to be developed again. If earnings of spiritual accounting referring to the letter of Al-Mukminun above, it then should be intended to improve prayer worship. Why improving the worship service becomes important for people who are in a company, let alone companies claiming to apply Islamic syar'ah? One of the Hadiths narrated from Abu Hurayrah, he heard the Prophet sallallaahu 'alaihi wa sallam said,

"Indeed, the charity of the first servant will be on the Day of Resurrection is Shalat. If his Shalat are good,..... "6

From verse 2 of Al-Mukminun and Hadist above, if the company gets the profit then the first and main observation is to improve the worship because Shalat is the first time as hisab. Why is this important and relevant? Ash-Shiddieqy (1966) with very huge information explains the various classes of people who do shalat. Among them are groups of people who pray at will without rukun and shalat syarah or widely called as shalat because of tradition or ritual. Therefore, it is undoubtedly that the company's obligation to utilize the profitability of such profits to improve its prayer worship.

The third verse "al-Laghwu" is against the things that are not useful (inefficient and ineffectiveness).

In the 4th verse related to zakat, that corporate profits are used to pay zakat. Zakat is a treasure worship that is obliged as a contribution to society aimed at guaranteeing cooperation and mobilizing socio-economic activities of the ummah, social security system, the guidance and economic development of socials to establish the religion of Islam, not to mention reinforce the value of social justice and become the viable solution to the problem of poverty, etc. It is expected that such profits will benefit the families or individuals of the company. Why it is important? Husbands who leave their wives and children are obliged to provide for them.

An-Nisa: 19; "And mingle you (husbands) with them (wives) as well".

Al-Baqarah: 228; "And the Wives have a right equal to their obligations in the way that Ma'ruf"

Hadist by Tirmidhi: "The best of you are the best to the family (his wife) and I am the best among you to the family (my wife)."

Profit in verse 8 is intended for people who hold the trust. The people who are in the company who get mandate to occupy a position, as a bonus.

\section{CONCLUSION}

Deconstruction of Profit in shari'a is based on the Qur'an and Hadith as the primary and absolute key; the world and everything belongs to Allah SWT, man only as a representative (khalifah), and used in order to worship. Which is utilized by the company should in order to increase worship to Allah SWT in Quran Al-Mukminun verses 1-11.

\section{Limitations}

This article is certainly still have many shortcomings, is only on the letter of Al-Mu'minun 1-11. There are still many Qur'anic verses and hadiths as well as its examples from the Prophet and the Companions of RadhiAllahu'anhu which need to be studied and interpreted into the business activities of a shari'ah enterprise entity. As an example, the story of Abu Bakr who surrendered all the treasures at the time of the Tabuk war, or the story of Sa'd ibn Rabi'a, Abdurrahman ibn Rauf.

\section{REFERENCE}

[1] Abdul Rahim Abdul-Rahman and Andrew Goddard. An Interpretive Inquiry of accounting Practices In Religious Organisations, Financial Accountability \& Management, 14 (3), August 1998, 0267-4424. 1998.

[2] Ahmed Eltegani Abudl Gader. Accounting Postulates And Principles From An Islamic Perspective Review Of Islamic Economics, Vo1.3, No.2, (1994), Pp. 1-18. 1994.

[3] Ahmed Belkaoui. Accounting Theory, 2nd edition, Harcourt Brace Jovanovich, Inc., N.Y., London, 1985, p. 220. 1985.

[4] Alim, Mohammad Nizarul. Akuntansi Syariah; Esensi, Konsep, Epistimologi, dan Metodologi. Jurnal Investasi Vol.7 No.2 Desember 2011. Hal. 134-161. 2011.

[5] Alim, Mohammad Nizarul. The Development Of Shari'ah Accounting: Epistemology Perspective. European Scientific Journal June 2014 /SPECIAL/ edition vol.1 ISSN: 1857 - 7881 (Print) e - ISSN 1857- 7431. 2014.

[6] Choudhury, M. A. Islamic Ekonomics and Finance: Where Do They Stand? 6th International Conference on Islamic Economics, Banking, and Finance, 21-24 November, Jakarta, Indonesia. 2005.

[7] Dechow, Patricia M., Sloan, Richard G. \& Jenny Zha. 2013. Stock Prices \& Earnings: A History of Research, Electronic copy available at: http://ssrn.com/abstract=2347193, October 18 , 2013.

[8] Harahap, S. S. Teori Akuntansi (13 ed.). Jakarta: Rajawali Pers. 2013.

[9] Mulyadi. Akuntansi Biaya Untuk Manajemen, BPFE, Yogyakarta. 1984.

[10] Riduwan, Akhmad., Triyuwono, Iwan., Irianto, Gugus., Unti Ludigdo. Semiotika Laba Akuntansi:Studi Kritikal-Posmodernis Derridean., Jurnal Akuntansi dan Keuangan Indonesia, Juni 2010, Vol. 7, No. 1 hal 38 - 60. 2010.

[11] Smith, Jay M dan Skousen, K. Fred. Akuntansi Intermediate, edisi 9 jilid 2. Erlangga, Jakarta. 1996.

[12] Suwardjono. Teori Akuntansi, Perekaysaan Pelaporan Keuangan. BPFE, Yogyakarta. 2005. 